\title{
ANALISIS MOTIVASI WISATAWAN DALAM BERBAGI PENGALAMAN WISATA MELALUI MEDIA SOSIAL INSTAGRAM
}

\author{
Lucky Nurdianisa $^{(1)}$, A. H. G. Kusumah, Sri Marhanah ${ }^{(3)}$ \\ (1)(2)(3)Program Studi Manajemen Resort \& Leisure \\ Universitas Pendidikan Indonesia \\ luckynurdianisa5@gmail.com
}

\begin{abstract}
ABSTRAK
Perkembangan teknologi dan media sosial telah memungkinkan para wisatawan untuk berbagi pengalaman wisata secara online. Berbagi pengalaman wisata adalah fenomena yang berkembang dalam pemasaran melalui media sosial. Mengingat sifat pengalaman wisata, berbagi informasi di media sosial diakui sebagai sumber informasi penting yang dapat mempengaruhi pengambilan keputusan wisata bagi calon wisatawan yang potensial. Metode penelitian yang digunakan dalam penelitian ini adalah metode penelitian survey dengan teknik analisis deskriptif dan pendekatan kuantitatif. Sampel yang ditetapkan dalam penelitian ini sebanyak 125 orang responden. Teknik analisis data yang digunakan adalah teknik analisis tabulasi silang dengan uji statistik chi-square dan data diolah menggunakan IBM SPSS Statistic versi 24. Hasil penelitian menunjukkan bahwa wisatawan yang berbagi pengalaman wisata melalui media sosial Instagram adalah wisatawan usia dewasa muda (youth traveller) dan mayoritas berjenis kelamin laki-laki. Dimensi self-centred motivation merupakan motivasi utama wisatawan dalam berbagi pengalaman wisata di media sosial Instagram dan memiliki frekuensi setuju tertinggi pada pernyataan "Saya ingin mendokumentasikan pengalaman wisata sebagai kenang-kenangan".
\end{abstract}

Kata kunci: motivasi berbagi, wisatawan, media sosial.

\section{MOTIVATION ANALYSIS OF TRAVELLER IN SHARING TRAVEL EXPERIENCES THROUGH SOCIAL MEDIA INSTAGRAM}

\begin{abstract}
The growth of technology and social media has enabled travellers to share their online travel experiences. Sharing the travel experience is a growing phenomenon in marketing through social media. Given the nature of tourist experience, shared information on social media sites is recognized as an important information source which may influence travel decision making for potential travellers. This research is using quantitative technique with descriptive survey method. The samples were determined in this research total of 125 respondents. Data analysis technique using cross tabulation with chi-square statistic test and processed by IBM SPSS Statistic version 24. The result revealed that most of travellers who shared their travel experience through social media Instagram are male and youth. Self-centred motivation dimension is the main motivation of travellers in sharing travel experiences with the highst agree frequency is with statement "I want to documment my travel experiences as memories".
\end{abstract}

Keywords: sharing motivation, traveler, social media. 


\section{PENDAHULUAN}

Teknologi kini tidak hanya mempengaruhi kehidupan dan perilaku sehari-hari tertapi juga mempengaruhi perkembangan industri pariwisata. Seiring dengan kemajuan teknologi, khusunya internet yang menjadi salah satu bagian terpenting dalam berbagi informasi. New media memperkenalkan kemungkinan baru untuk memberikan peluang dan tantangan bagi mereka yang terlibat dalam sektor pariwisata. Salah satu new media evolusi Web 1.0 yang dikenal sebagai Web 2.0 dalam berkomunikasi adalah media sosial. Kemajuan internet dan media sosial mengubah banyak cara informasi terkait pariwisata dan cara orang merencanakan serta melakukan wisata disebarluaskan. Perkembangan teknologi di bidang media sosial berbasis internet telah membuat wisatawan memungkinkan untuk berbagi cerita perjalanan mereka (Nezakati, et al., 2015).

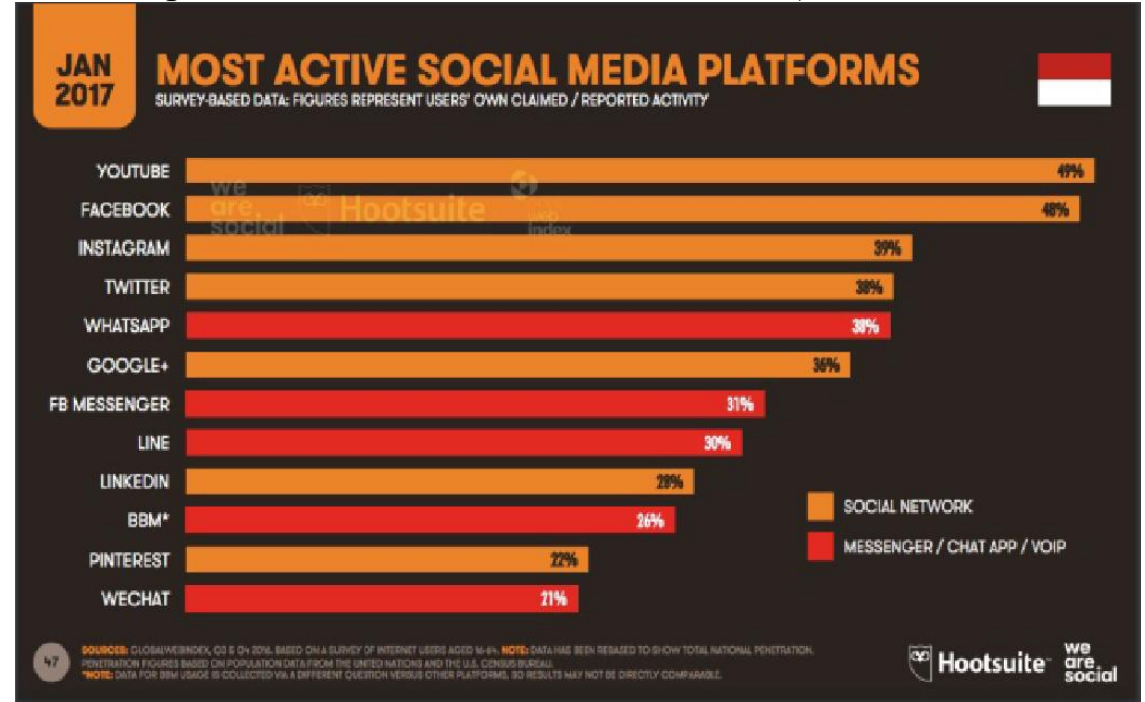

Gambar 1. Data Pengguna Media Sosial Berdasarkan Aplikasi Populer di Indonesia Sumber: slideshare.net

Jenis media sosial YouTube mendominasi pengguna aktif paling banyak di Indonesia sebesar 49\%, disusul oleh Facebook dengan pengguna aktif sebesar $48 \%$. Tingkat pertumbuhan Instagram sangat cepat dengan pengguna aktif mencapai 39\% atau sekitar 41,3 juta pengguna. Berdasarkan penelitian sebuah perusahaan riset dan analisis di Inggris, TNR, menyebutkan bahwa Indonesia berada pada peringkat ke-3 pengguna Instagram (id.techinasia.com).

Aplikasi berbagi foto dimana pengguna dapat menangkap momen dalam bentuk foto dan video, menerapkan filter digital, kemudian diunggah dan membagikannya ke berbagai layanan jejaring social adalah Instagram salah satu media sosial yang digunakan untuk menyebarkan informasi pariwisata. Instagram memberikan tampilan visual seperti gambar dan video yang memberikan keyakinan kepada wisatawan mengenai informasi yang ingin diperoleh. Adanya fasilitas seperti fotografi, geotagging, geolocation, dan hastag dapat mempermudah pengguna atau untuk berbagi informasi mengenai destinasi wisata.

Perilaku berbagi foto wisata di destinasi baru yang belum diketahui dan terjamah oleh banyak orang menjadi tren saat ini. Wisatawan masa kini cenderung mencari objek wisata yang menarik untuk didokumentasikan dan kemudian dibagikan melalui media sosial. Semakin banyaknya penggunaan media sosial, wisatawan lebih sering terlihat mengunggah foto dan pengalaman pribadi mengenai produk atau layanan di Instagram. Seiring meningkatnya praktek berbagi, semakin penting bagi para pelaku industri pariwisata untuk memahami perilaku wisatawan yang bersedia berbagi pengalaman wisata secara online. 
Wisatawan yang membagikan pengalaman wisata di media sosial Instagram memiliki karakteristik dan motivasi yang berbedabeda. Selain itu, Seiring meningkatnya praktek berbagi, semakin penting bagi para pelaku industri pariwisata untuk memahami perilaku wisatawan yang bersedia berbagi pengalaman wisata secara online. Berdasarkan beberapa artikel yang telah dibaca, banyaknya penelitian yang berfokus pada manfaat media sosial dalam promosi pariwisata dan keputusan berkunjung, namun masih sedikit studi yang membahas mengenai motivasi wisatawan dalam melakukan praktik berbagi di media sosial. Oleh sebab itu dilakukan penentuan rumusan masalah dalam penelitian ini sebagai berikut:

1. Bagaimana karakteristik wisatawan yang membagikan pengalaman wisatanya di media sosial Instagram?

2. Bagaimana motivasi wisatawan dalam berbagi pengalaman wisata berdasarkan karakteristik?

Penelitian ini dituangkan dalam bentuk skipsi dengan judul "Motivasi Wisatawan dalam Berbagi Pengalaman Wisata melalui Media Sosial Instagram" dan mengacu pada penelitian sebelumnya yaitu artikel jurnal Munar \& Jacobsen (2014) dengan judul "Motivations For Sharing Tourism Experiences Through Social Media". Tujuan dari penelitian ini adalah untuk mengetahui motivasi wisatawan dalam berbagi pengalaman wisata melalui media sosial Instagram dan peranan kemajuan internet dan media sosial dalam mengubah penyebaran informasi pariwisata.

\section{LANDASAN TEORI}

\section{Definisi dan Karakteristik Wisatawan}

Berdasarkan Undang-Undang Nomor 10 Tahun 2009 Tentang Kepariwisataan, bahwa wisatawan adalah orang-orang yang melakukan kegiatan wisata. Menurut Suswantoro (1997) wisatawan adalah seseorang atau kelompok orang yang melakukan suatu perjalanan wisata jika lama tinggalnya sekurang-kurangnya 24 jam di daerah atau negara yang dikunjungi. Dengan demikian, wisatawan dapat didefinisikan sebagai seseorang atau sekelompok orang yang melakukan perjalanan wisata dengan apapun tujuannya, perjalanan itu bukan untuk menetap dan tidak untuk mencari nafkah ditempat yang dikunjungi.

Wisatawan memiliki beberapa karakteristik. Menurut Kotler dan Cooper (dalam Ismayanti, 2010:41) karakteristik wisatawan dibedakan menjadi 3, yaitu:

1. Karakteristik Wisatawan Berdasarkan Psikografi

Dalam psikografi, wisatawan dipilahpilah berdasakan kepribadian individu, gaya hidup, dan kelas sosial.

2. Karakteristik Wisatawan Berdasarkan Demografis

Klasifikasi wisatawan ini dibedakan berdasarkan usia, latar belakang pendidikan, pendapatan, jenis kelamin, dan siklus keluarga. Sifat wisatawan erat terkait umur karena berdampak pada kegiatan wisata yang dilakukan.

3. Karakteristik Wisatawan Berdasarkan Geografis

Wisatawan yang dibedakan berdasarkan aspek geografis adalah wisatawan yang dibedakan berdasarkan tempat tinggal atau asal wisatawan. Daerah asal wisatawan merupakan aspek penting dalam memahami karakteristik wisatawan karena hal tersebut berkaitan dengan kebudayaan, nilai, sikap, kepercayaan, dan sistem.

\section{Konsep Travel Experience Sharing}

Berbagi pengalaman merupakan modifikasi dari studi mengenai berbagi pengetahuan dalam konteks pariwisata secara keseluruhan. Menurut Kang \& Schuett (2013) Berbagi pengalaman perjalanan wisata di media sosial adalah perilaku atau aktivitas yang terjadi saat seseorang menyebarkan pengalaman terkait perjalanan wisata kepada anggota lain melalui media sosial. Di industri pariwisata, berbagi pengetahuan menunjuk pada keinginan anggota perjalanan untuk bertukar pengalamannya dengan anggota lainnya. 
Berbagi pengetahuan melibatkan anggota masyarakat dalam berbagai kegiatan termasuk berbagi pengalaman, keterampilan, pengetahuan dan minat (Ridings, Gefen, \& Arinze, 2002).

Munar \& Jacobsen (2014) mengelompokkan faktor-faktor pendorong motivasi wisatawan dalam berbagi pengalaman wisata melalui media sosial menjadi 2 kelompok besar, yaitu:

\section{Self-centred motivation}

Self-centred motivation atau motivasi yang bersifat intrinsik, yaitu harapan wisatawan secara personal (personal expectations) yang membawa kepada motivasi terpusat pada diri sendiri (selfcentred) yang lebih luas. Berikut merupakan yang termasuk dalam selfcentred motivation antara lain:

a. Contribute to websites that are useful

b. Maintain social connections and friendship

c. Share impressions through the internet

d. To be more recognized

\section{Community-related motivation}

Community-related motivation atau motivasi ekstrinsik, yaitu motivasi yang berfokus pada harapan wisatawan mengenai dampak yang mungkin terjadi dari pengalaman online di komunitas virtual atau para pengguna media sosial lainnya mengenai akibat yang mungkin terjadi dengan berbagi pengalaman secara online dalam komunitas virtual atau para pengguna media sosial lainnya untuk membantu masyarakat dalam mencapai tujuan. Termasuk rasa solidaritas serta sebagai bagian dari komunitas. Motivasi community-related berupaya untuk menolong orang lain dan mencegah orang lain dari penggunaan produk wisata yang buruk.
a. Help others
b. Prevent people from using bad products

\section{METODE}

Penelitian ini menggunakan metode penelitian deskriptif dengan pendekatan kuantitatif. Teknik pengambilan sampel yang digunakan adalah teknik nonprobability sampling dengan metode purposive sampling. Purposive sampling adalah teknik pengambilan sampel sumber data dengan pertimbangan tertentu (Sugiyono, 2017). Hal ini karena tidak semua sampel sesuai dengan kriteria yang ditentukan, yaitu: responden usia minimal 18 tahun, pernah melakukan perjalanan wisata selama 2 tahun terakhir, dan menggunakan media sosial Instagram sebagai media untuk berbagi pengalaman wisata. Jumlah sampel dalam penelitian ini sebanyak 125 orang responden.

Jenis dan sumber data primer dalam penelitian ini berdasarkan hasil survey menggunakan instrumen berupa kuesioner secara online melalui aplikasi Google Form. Sedangkan data sekunder dalam penelitian ini diambil dari penelitian terdahulu maupun teori yang diperoleh secara tidak langsung melalui buku-buku, internet dan artikel jurnal yang berkaitan dengan Knowledge Sharing Motivation dan Travel Experience Sharing Motivation. Kuesioner penelitian dibagi menjadi 2 bagian, yaitu: (i) profil demografis dan penggunaan media sosial Instagram; (ii) motivasi berbagi, self-centred motivation dan community-related motivation.

Pada bagian kedua untuk konstruk variabel sharing motivation diberi pilihan jawaban item sangat tidak setuju, tidak setuju, netral, setuju, dan sangat tidak setuju. Sikap netral dianggap sebagai pensamaran sikap setuju, maka pada penelitian ini, item netral dimasukkan dalam kategori setuju.

Pengujian dan pengolahan data dalam penelitian ini menggunakan program SPSS 24.0 for Windows. Pengolahan data yang digunakan adalah uji validitas dan reliabilitas untuk mengetahui layak tidaknya variabel dalam penelitian ini.

Uji validitas dilakukan pada setiap butir daftar pernyataan. Daftar pernyataan dinyatakan valid apabila hasil rhitung $\mathrm{r}_{\text {tabel }}<$ $\mathrm{r}_{\text {hitung }}$ dengan nilai signifikan 5\%.

Selanjutnya uji reliabilitas dilakukan pada seluruh butir pernyataan dalam instumen 
yang valid untuk diuji ketepatan keakuratan dan kemantapan suatu instrumen dengan menggunakan rumus Alpha Cronbach. Daftar pernyataan dinyatakan reliabel jika nilai alpha $>0,60$.

Setelah data dinyatakan valid dan reliabel maka penelitian dilanjutkan ke tahap selanjutnya yaitu proses analisis tabulasi silang dengan uji chi-square.

\section{HASIL DAN PEMBAHASAN}

\section{Karakteristik Responden}

1. Karakteristik Responden Berdasarkan Sosio-Demografis

Dari 125 orang responden yang menjadi sampel dalam penelitian ini, dilakukan pembedaan terhadap jenis kelamin responden.

a. Jenis kelamin

Dalam penelitian ini, dilakukan pembedaan terhadap jenis kelamin responden. Diketahui bahwa responden didominasi oleh laki-laki sebanyak 77 orang responden dengan presentase $61,6 \%$ dan 48 orang responden perempuan dengan presentase 38,4\%. Dengan demikian, dapat disimpulkan bahwa mayoritas wisatawan berbagi pengalaman wisatanya di media sosial Instagram adalah berjenis kelamin lakilaki. Berdasarkan penelitian Grijalva et al. (2015) mengenai perbedaan gender dalam narsisme yang didorong dari 3 aspek Narcissistic Personality Inventory (kepemimpinan/ otoritas, eksibisionisme/ sifat pamer, dan perasaan berhak atas prioritas) mengklaim bahwa pria secara konsisten lebih narsis dibandingkan wanita. Seperti halnya perempuan, lakilaki juga kerap mengunggah foto mereka ke media sosial. Laki-laki jarang mengungkapkan perasaannya secara langsung, media sosial digunakan untuk mengungkapkan pikiran-pikiran, seperti mengunggah foto dengan caption menceritakan pengalaman wisata. Jadi, dapat dikatakan bahwa laki-laki lebih narsis dibandingkan dengan perempuan.

b. Usia
Responden berdasarkan usia dengan presentase tertinggi terdapat pada usia 21 - 30 tahun yaitu sebanyak 108 orang responden dengan presentase $86,4 \%$ dan terendah pada usia $>50$ tahun yaitu 0 atau tidak ada. Hal ini menunjukan bahwa wisatawan berbagi pengalaman wisata di Instagram adalah remaja akhir hingga dewasa karena pada masa itu merupakan usia produktif dan memiliki keingintahuan yang tinggi. Menurut $P e w$ Internet \& American Life Project (dalam Yoo \& Gretzel, 2008) mengenai penggunaan dan dampak dari ulasan wisata secara online mengklaim bahwa bagi usia muda, penggunaan internet terutama media sosial adalah hal yang sudah biasa, bahkan sudah menjadi kebutuhan pribadi. Pengguna Internet yang lebih muda cenderung menjadi pembuat konten secara online.

c. Latar belakang pendidikan

Tingkat pendidikan yang dimaksud adalah pendidikan terakhir responden yang membagikan pengalaman wisatanya melalui media sosial Instagram didominasi oleh responden dengan pendidikan terakhir Sarjana (S1) yaitu sebanyak 89 orang responden, adapun SMA sebanyak 21 orang responden, Diploma sebanyak 11 orang responden, Magister (S2) sebanyak 4 orang responden, dan Doktor (S3) 0 atau tidak ada. Berdasarkan data hasil penelitian tersebut, dapat disimpulkan bahwa mayoritas responden bergelar Sarjana (S1). Kondisi ini menunjukkan dengan jelas bahwa wisatawan yang membagikan pengalaman wisatanya melalui Instagram memiliki latar belakang pendidikan yang tinggi. Pengguna internet dengan intensitas tinggi ialah mereka yang memiliki tingkat pendidikan tinggi, artinya semakin tinggi tingkat pendidikannya, maka semakin sering pula intensitas mereka untuk mengakses internet dan berbagi pengalaman wisatanya di Instagram. 
2. Karakteristik Responden Berdasarkan Geografis

Responden yang membagikan pengalaman wisatanya melalui media sosial Instagram dinominasi oleh wisatawan asal Bandung sebanyak 32 orang responden dengan presentase 26\%. Mengingat kota tersebut termasuk dalam 10 kota terbesar di Indonesia dengan aktivitas online tertinggi. Selain itu, wisatawan asal Jakarta sebanyak 22 orang responden, asal Surabaya sebanyak 3 orang responden, asal Medan sebanyak 2 orang responden, dan lainnya seperti Yogyakarta, Denpasar, dll. sebanyak 66 orang responden.

3. Karakteristik Responden Berdasarkan Psikografis

a. Durasi perjalanan

Berdasarkan durasi perjalanan, menjukkan bahwa sebanyak 46 orang responden pergi berwisata selama $1-3$ hari, 60 orang responden pergi berwisata selama $4-7$ hari, 8 orang responden pergi berwisata selama $8-10$ hari, 4 orang responden pergi berwisata selama $11-14$ hari, dan 7 orang responden pergi berlibur selama $>14$ hari. Berdasarkan data hasil penelitian tersebut, dapat disimpulkan bahwa sebagian besar responden pergi berwisata selama $4-7$ hari yaitu 60 orang responden dengan presentase $48 \%$. Hal ini menunjukan bahwa dengan durasi perjalanan tersebut sudah mulai banyak pengalaman dan momen yang akan dibagikan jauh lebih banyak, seperti membagikan foto liburan dan sebagaiannya.

b. Keaktifan berbagi pengalaman wisata Wisatawan berbagi/ mengunggah pengalaman wisatanya melalui media sosial Instagram $>3$ kali dalam 51 orang responden dengan presentase 40,8\%. Disusul oleh wisatawan yang mengunggah pengalaman wisata 1 kali sebanyak 41 orang responden, 2 kali sebanyak 20 orang responden, dan 3 kali sebanyak 13 orang responden.

c. Penggunaan internet selama berwisata

Sebanyak 122 orang resonden menggunakan internet selama berwisata, sedangkan 3 orang responden lainnya tidak menggunakan internet selama berwisata. Dengan demikian, terlihat bahwa 122 orang responden dengan presentase $97,6 \%$ dari 125 orang responden yang berarti hampir semua responden menggunakan internet selama berwisata biasanya digunakan untuk mencari informasi mengenai destinasi wisata yang menarik (termasuk petunjuk arah), berkomunikasi dengan orang-orang terdekat, menyimpan foto wisata secara online, dan mengunggah foto serta pengalaman wisatanya di media sosial. Dengan menggunakan media sosial wisatawan atau konsumen dapat membagikan pengalaman mereka serta bisa juga digunakan sebagai sumber dalam pencarian informasi mengenai destinasi wisata (Gohil, 2015).

Hasil Tabulasi Silang Karakteristik Wisatawan dengan Motivasi Berbagi (Sharing Motivation)

1. Demografis

Motivasi wisatawan dalam berbagi pengalaman wisatanya di media sosial Instagram berdasarkan karakteristik demografis yang diuji dalam penelitian ini ada 2, yaitu: jenis kelamin dan usia.

a. Jenis kelamin dengan motivasi berbagi (sharing motivation) 
Lucky Nurdianisa, A. H. Galih Kusumah dan Sri Marhanah: Analisis Motivasi Wisatawan dalam Berbagi Pengalaman Wisata Melalui Media Sosial Instagram

Tabel 1. Tanggapan Responden Terhadap Dimensi Sharing Motivation Berdasarkan Jenis Kelamin

\begin{tabular}{|c|c|c|c|c|c|c|c|c|c|}
\hline \multirow[b]{3}{*}{ No } & \multirow[b]{3}{*}{ Pernyataan } & \multicolumn{8}{|c|}{ Jenis Kelamin } \\
\hline & & \multicolumn{4}{|c|}{ Laki-laki } & \multicolumn{4}{|c|}{ Perempuan } \\
\hline & & $\begin{array}{c}\text { Setuju } \\
(\%)\end{array}$ & $\begin{array}{l}\text { Tidak } \\
\text { Setuju } \\
(\%)\end{array}$ & $\mathrm{F}$ & $\mathrm{N}$ & $\begin{array}{l}\text { Setuju } \\
(\%)\end{array}$ & $\begin{array}{l}\text { Tidak } \\
\text { Setuju } \\
(\%)\end{array}$ & $\mathrm{F}$ & N \\
\hline \multicolumn{10}{|c|}{ Self-Centred Motivation } \\
\hline 1. & $\begin{array}{l}\text { Saya ingin berkontribusi } \\
\text { terhadap hastags yang berguna } \\
\text { bagi saya }\end{array}$ & 46,4 & $15,2^{*}$ &, 000 & 77 & 20,0 & 18,4 &, 773 & 48 \\
\hline 2. & $\begin{array}{l}\text { Saya ingin menemukan teman } \\
\text { yang memiliki minat yang sama } \\
\text { dalam berwisata }\end{array}$ & 53,6 & $8,0^{*}$ &, 000 & 77 & 24,0 & 14,4 &, 083 & 48 \\
\hline 3. & $\begin{array}{l}\text { Saya senang berbagi } \\
\text { pengalaman wisata di media } \\
\text { sosial Instagram }\end{array}$ & 56,8 & $4,8^{*}$ &, 000 & 77 & 32,0 & $6,4^{*}$ & ,000 & 48 \\
\hline 4. & $\begin{array}{l}\text { Saya ingin meningkatkan } \\
\text { eksistensi diri di media sosial } \\
\text { Instagram }\end{array}$ & 34,4 & 27,2 & ,305 & 77 & 13,6 & $24,8^{*}$ & ,043 & 48 \\
\hline 5. & $\begin{array}{l}\text { Saya ingin mendokumentasikan } \\
\text { pengalaman wisata sebagai } \\
\text { kenang-kenangan }\end{array}$ & 59,2 & $2,4^{*}$ &, 000 & 77 & 33,6 & $4,8^{*}$ &, 000 & 48 \\
\hline 6. & $\begin{array}{l}\text { Sebagai back-up file jika file asli } \\
\text { di komputer hilang }\end{array}$ & 44,8 & $16,8^{*}$ &, 000 & 77 & 26,4 & $12,0^{*}$ &, 009 & 48 \\
\hline \multicolumn{10}{|c|}{ Community-Related Motivation } \\
\hline & $\begin{array}{l}\text { Saya ingin berbagi informasi } \\
\text { wisata yang berguna bagi } \\
\text { wisatawan lain }\end{array}$ & 58,4 & $3,2^{*}$ &, 000 & 77 & 28,8 & $9,6^{*}$ &, 001 & 48 \\
\hline 8. & $\begin{array}{l}\text { Sebagai bahan referensi untuk } \\
\text { wisatawan lain }\end{array}$ & 58,8 & $2,8^{*}$ &, 000 & 77 & 29,6 & $8,8^{*}$ & ,000 & 48 \\
\hline 9. & $\begin{array}{l}\text { Saya ingin membantu } \\
\text { mempromosikan destinasi } \\
\text { wisata tersebut }\end{array}$ & 57,6 & $4,0^{*}$ &, 000 & 77 & 28,8 & $9,6^{*}$ & 001 & 48 \\
\hline
\end{tabular}

Sumber: Pengolahan data dengan SPSS 24.0

Responden berdasarkan jenis kelamin baik laki-laki maupun perempuan setuju membagikan pengalaman wisatanya melalui media sosial Instagram. Hal ini diketahui dari presentase pada kolom "Setuju" lebih besar dibandingkan dengan kolom "Tidak Setuju". Untuk responden laki-laki menunjukkan perbedaan yang signifikan dengan motivasi tertinggi ada pada pernyataan "Saya ingin mendokumentasikan pengalaman wisata di media sosial Instagram". Untuk responden perempuan, pernyataan motivasi tertinggi pada pernyataan "Saya ingin mendokumentasikan pengalaman wisata di media sosial Instagram".
Responden laki-laki maupun perempuan menunjukkan tingkat identifikasi yang lebih tinggi pada dimensi self-centred motivation. Perbedaan tersebut ada pada variabel dokumentasi pribadi. Bakan (dalam Yoo \& Gretzel, 2008) berpendapat bahwa lakilaki dikendalikan oleh tujuan yang berfokus pada diri sendiri. Laki-laki secara tradisional didorong oleh selfefficacy, self-assertion, dan orientasi pencapaian. Namun, tidak bagi wisatawan ini, bukan hanya laki-laki tetapi juga responden perempuan didorong oleh motivasi yang berfokus pada diri sendiri. Artinya, baik responden laki-laki maupun 
perempuan memiliki motivasi yang sama dalam membagikan pengalaman wisatanya melalui media sosial Instagram. Ketika wisatawan rindu dengan masa lalu atau momen-momen saat berwisata, mereka dapat meninjau kembali hasil dokumentasi foto, video, maupun cerita perjalanan wisata mereka di media sosial.

b. Usia dengan motivasi berbagi (sharing motivation)

Tabel 2. Tanggapan Responden Terhadap Dimensi Sharing Motivation Berdasarkan Usia

\begin{tabular}{|c|c|c|c|c|c|c|c|c|c|}
\hline \multirow[b]{3}{*}{ No } & \multirow[b]{3}{*}{ Pernyataan } & \multicolumn{8}{|c|}{ Usia } \\
\hline & & \multicolumn{4}{|c|}{$<30$ Tahun } & \multicolumn{4}{|c|}{$<30$ Tahun } \\
\hline & & $\begin{array}{c}\text { Setuju } \\
(\%)\end{array}$ & $\begin{array}{l}\text { Tidak } \\
\text { Setuju } \\
(\%)\end{array}$ & $\mathrm{F}$ & $\mathrm{N}$ & $\begin{array}{c}\text { Setuju } \\
(\%)\end{array}$ & $\begin{array}{l}\text { Tidak } \\
\text { Setuju } \\
(\%)\end{array}$ & $\mathrm{F}$ & N \\
\hline \multicolumn{10}{|c|}{ Self-Centred Motivation } \\
\hline & $\begin{array}{l}\text { Saya ingin berkontribusi } \\
\text { terhadap hastags yang } \\
\text { berguna bagi saya }\end{array}$ & 59,2 & $32,8^{*}$ & ,002 & 115 & 6,4 & 1,6 & ,058 & 10 \\
\hline & $\begin{array}{l}\text { Saya ingin menemukan teman } \\
\text { yang memiliki minat yang sama } \\
\text { dalam berwisata }\end{array}$ & 72,0 & $20,0^{*}$ &, 000 & 115 & 5,6 & 2,4 & ,206 & 10 \\
\hline & $\begin{array}{l}\text { Saya senang berbagi } \\
\text { pengalaman wisata di media } \\
\text { sosial Instagram }\end{array}$ & 81,6 & $10,4^{*}$ & ,000 & 115 & 7,2 & $0,8^{*}$ &, 011 & 10 \\
\hline & $\begin{array}{l}\text { Saya ingin meningkatkan } \\
\text { eksistensi diri di media sosial } \\
\text { Instagram }\end{array}$ & 42,4 & 49,6 & ,401 & 115 & 6,4 & 1,6 &, 058 & 10 \\
\hline 5. & $\begin{array}{l}\text { Saya ingin } \\
\text { mendokumentasikan } \\
\text { pengalaman wisata sebagai } \\
\text { kenang-kenangan } \\
\end{array}$ & 85,6 & $6,4^{*}$ &, 000 & 115 & 8,0 & 0 & 0 & 10 \\
\hline 6. & $\begin{array}{l}\text { Sebagai back-up file jika file } \\
\text { asli di komputer hilang }\end{array}$ & 66,4 & $25,6^{*}$ & ,000 & 115 & 5,6 & 2,4 & ,206 & 10 \\
\hline \multicolumn{10}{|c|}{ Community-Related Motivation } \\
\hline & $\begin{array}{l}\text { Saya ingin berbagi informasi } \\
\text { wisata yang berguna bagi } \\
\text { wisatawan lain }\end{array}$ & 80,0 & $3,2^{*}$ & 000 & 77 & 28,8 & $9,6^{*}$ & 001 & 48 \\
\hline 8. & $\begin{array}{l}\text { Sebagai bahan referensi untuk } \\
\text { wisatawan lain }\end{array}$ & 80,8 & $2,8^{*}$ & ,000 & 77 & 29,6 & $8,8^{*}$ & ,000 & 48 \\
\hline 9. & $\begin{array}{l}\text { Saya ingin membantu } \\
\text { mempromosikan destinasi } \\
\text { wisata tersebut }\end{array}$ & 78,4 & $4,0^{*}$ & ,000 & 77 & 28,8 & $9,6^{*}$ & ,001 & 48 \\
\hline
\end{tabular}

Sumber: Pengolahan data dengan SPSS 24.0

Responden berdasarkan kelompok usia $<30$ tahun merupakan kelompok responden yang dominan sebanyak 115 orang responden. Sementara untuk kelompok responden $>31$ tahun sebanyak 10 orang responden. Kelompok responden $<30$ tahun menunjukkan perbedaan yang signifikan terhadap pernyataan motivasi tertinggi dengan pernyataan "Saya ingin mendokumentasikan pengalaman wisata di media sosial Instagram" sebesar $85,6 \%$. Sedangkan untuk kelompok usia responden $>31$ tahun tidak dapat 
dianalisis datanya karena ada beberapa pernyataan yang tidak menunjukan hasil yang signifikan dan ada beberapa pernyataan dengan jumlah yang sedikit. Namun, jika tanpa memperhatikan hasil uji chi-square dan jumlah responden, kelompok responden dengan usia $>30$ tahun memiliki motivasi dengan pernyataan "Saya senang berbagi pengalaman wisata di media sosial Instagram" dan "Saya ingin membantu mempromosikan destinasi wisata tersebut" dengan presentase masingmasing $7,2 \%$.

Berdasarkan usia, menunjukkan tingkat identifikasi yang lebih tinggi pada dimensi self-centred motivation. Perbedaan tersebut ada pada variabel dokumentasi pribadi dan kesenangan dalam berbagi pengalaman. Wisatawan muda memfokuskan diri pada penggunaan internet, ketika wisatawan generasi muda melakukan sebuah perjalanan wisata sebagian besar mereka berbagi foto dan cerita mereka merupakan kepuasan tersendiri saat dapat merekam perjalanan wisata di media sosial. Pengguna media sosial dengan umur lebih muda memanfaatkan media sosial untuk mendokumentasikan dan berbagi kehidupan mereka (Lenhart \& Fox, 2006).

2. Psikografis

Motivasi wisatawan dalam berbagi pengalaman wisatanya di media sosial Instagram berdasarkan karakteristik psikografis yang diuji dalam penelitian ini adalah penggunaan internet wisatawan.

Penggunaan internet dengan motivasi berbagi (sharing motivasi).

Tabel 3. Tanggapan Responden Terhadap Dimensi Sharing Motivation Berdasarkan Penggunaan Internet

\begin{tabular}{|c|c|c|c|c|c|c|c|c|c|}
\hline \multirow[b]{3}{*}{ No. } & \multirow[b]{3}{*}{ Pernyataan } & \multicolumn{8}{|c|}{ Penggunaan Internet Selama Berwisata } \\
\hline & & \multicolumn{4}{|c|}{ Menggunakan Internet } & \multicolumn{4}{|c|}{ Menggunakan Internet } \\
\hline & & $\begin{array}{l}\text { Setuju } \\
(\%)\end{array}$ & $\begin{array}{l}\text { Tidak } \\
\text { Setuju } \\
(\%)\end{array}$ & $\mathrm{F}$ & $\mathrm{N}$ & $\begin{array}{c}\text { Setuju } \\
(\%)\end{array}$ & $\begin{array}{c}\text { Tidak } \\
\text { Setuju } \\
(\%)\end{array}$ & $\mathrm{F}$ & $\mathrm{N}$ \\
\hline \multicolumn{10}{|c|}{ Self-Centred Motivation } \\
\hline 1. & $\begin{array}{l}\text { Saya ingin berkontribusi terhadap } \\
\text { hastags yang berguna bagi saya }\end{array}$ & 64,0 & 33,6 &, 001 & 122 & ,8 & 1,6 &, 564 & 3 \\
\hline 2. & $\begin{array}{l}\text { Saya ingin menemukan teman } \\
\text { yang memiliki minat yang sama } \\
\text { dalam berwisata }\end{array}$ & 76,0 & $21,6^{*}$ &, 000 & 122 & 1,6 & 8 &, 564 & 3 \\
\hline 3. & $\begin{array}{l}\text { Saya senang berbagi } \\
\text { pengalaman wisata di media } \\
\text { sosial Instagram }\end{array}$ & 87,2 & $10,4^{*}$ &, 000 & 122 & 1,6 & , 8 &, 546 & 3 \\
\hline & $\begin{array}{l}\text { Saya ingin meningkatkan } \\
\text { eksistensi diri di media sosial } \\
\text { Instagram }\end{array}$ & 47,2 & 50,4 & ,717 & 122 & 1,6 & ,8 &, 546 & 3 \\
\hline 5. & $\begin{array}{l}\text { Saya ingin mendokumentasikan } \\
\text { pengalaman wisata sebagai } \\
\text { kenang-kenangan }\end{array}$ & 91,2 & $6,4^{*}$ &, 000 & 122 & 2,4 & 0 & 0 & 3 \\
\hline 6. & $\begin{array}{l}\text { Sebagai back-up file jika file asli } \\
\text { di komputer hilang }\end{array}$ & 70,4 & $27,2^{*}$ &, 000 & 122 & , 8 & 1,6 &, 546 & 3 \\
\hline \multicolumn{10}{|c|}{ Community-Related Motivation } \\
\hline 7. & $\begin{array}{l}\text { Saya ingin berbagi informasi } \\
\text { wisata yang berguna bagi } \\
\text { wisatawan lain }\end{array}$ & 86,4 & $11,2^{*}$ &, 000 & 122 & 2,4 & 0 & 0 & 3 \\
\hline 8. & $\begin{array}{l}\text { Sebagai bahan referensi untuk } \\
\text { wisatawan lain }\end{array}$ & 86,4 & $11,2^{*}$ &, 000 & 122 & 2,4 & 0 & 0 & 3 \\
\hline
\end{tabular}




\begin{tabular}{|c|c|c|c|c|c|c|c|c|c|}
\hline \multirow[b]{3}{*}{ No. } & \multirow[b]{3}{*}{ Pernyataan } & \multicolumn{8}{|c|}{ Penggunaan Internet Selama Berwisata } \\
\hline & & \multicolumn{4}{|c|}{ Menggunakan Internet } & \multicolumn{4}{|c|}{ Menggunakan Internet } \\
\hline & & $\begin{array}{c}\text { Setuju } \\
(\%)\end{array}$ & $\begin{array}{l}\text { Tidak } \\
\text { Setuju } \\
(\%)\end{array}$ & $F$ & $\mathrm{~N}$ & $\begin{array}{l}\text { Setuju } \\
(\%)\end{array}$ & $\begin{array}{l}\text { Tidak } \\
\text { Setuju } \\
(\%)\end{array}$ & $\mathrm{F}$ & $\mathrm{N}$ \\
\hline 9. & $\begin{array}{l}\text { Saya ingin membantu } \\
\text { mempromosikan destinasi wisata } \\
\text { tersebut }\end{array}$ & 84,0 & $13,6^{*}$ &, 000 & 122 & 1,6 & , 8 &, 546 & 3 \\
\hline
\end{tabular}

Sumber: Pengolahan data dengan SPSS 24.0

Berdasarkan kelompok responden yang menggunakan Internet selama berwisata merupakan kelompok responden yang dominan sebanyak 122 orang responden. Sedangkan kelompok responden yang tidak menggunakan internet selama berwisata sebanyak 3 orang responden. Secara keseluruhan, baik responden yang menggunakan dan responden yang tidak menggunakan internet selama berwisata memiliki motivasi untuk berbagi pengalaman wisata melalui media sosial Instagram. Hal tersebut dapat dibuktikan dengan presentase terbesar pada kolom "Setuju" dibandingkan kolom "Tidak setuju".

Tabel 3 menunjukkan untuk kelompok responden yang menggunakan internet selama berwisata memiliki perbedaan signifikan tertinggi terhadap motivasi pada pernyataan "Saya ingin mendokumentasikan pengalaman wisata di media sosial Instagram" sebesar 91,2\%. Sedangkan untuk kelompok responden yang tidak menggunakan Internet selama berwisata tidak dapat dianalisis datanya karena nilai $P$ Value di atas $0,05 \%$ terhadap beberapa pernyataan motivasi.

Unggahan foto, video, dan cerita wisata di media sosial adalah salah satu bentuk dokumentasi yaitu sebagai suatu sarana untuk mengenang peristiwa wisata. Wisatawan didasari oleh faktor asosiasi sosial yang diharapkan dengan mendokumentasikan pengalaman wisatanya di media sosial Instagram merupakan kepuasan tersendiri saat berhasil merekam perjalanan.

\section{KESIMPULAN}

Berdasarkan hasil penelitian dan pengolahan data yang dilakukan peneliti mengenai faktor motivasi wisatawan dalam berbagi pengalaman wisata melalui media sosial Instagram dikaitkan dengan karakteristik wisatawan dapat ditarik simpulan sebagai berikut:

1. Hasil yang didapatkan dari penyebaran kuesioner dilihat dari yang merespon, responden laki-laki lebih mendominasi sebanyak 77 orang dengan usia berkisar 21 - 30 tahun atau disebut juga young adult (youth traveler) dan memiliki latar belakang Sarjana (S1), dimana pengguna internet yang lebih muda cenderung menjadi pembuat konten secara online karena pada usia ini penggunaan internet terutama media sosial adalah hal yang sudah biasa, bahkan sudah menjadi kebutuhan sehari-hari. Rata-rata responden berasal dari Kota Bandung, menggunakan internet selama berwisata dan aktif dalam mengunggah pengalaman wisata di media sosial Instagram sebanyak $>3$ kali dalam seminggu. Dengan menggunakan media sosial, wisatawan dapat membagikan pengalaman wisata mereka serta dapat digunakan sebagai sumber dalam pencarian informasi mengenai destinasi wisata.

2. Dari hasil analisis tabulasi silang dan uji chi-square pada setiap kategori karakteristik wisatawan (jenis kelamin, usia, asal daerah, dan penggunaan internet selama liburan) dengan motivasi berbagi (sharing motivation) diperoleh hasil bahwa secara keseluruhan wisatawan memiliki motivasi yang 
Lucky Nurdianisa, A. H. Galih Kusumah dan Sri Marhanah: Analisis Motivasi Wisatawan dalam Berbagi Pengalaman Wisata Melalui Media Sosial Instagram

mengarah pada self-centred motivation pada pernyataan "Saya ingin mendokumentasikan pengalaman wisata sebagai kenang-kenangan". Unggahan foto, video, dan cerita wisata di media sosial adalah salah satu bentuk dokumentasi yaitu sebagai suatu sarana untuk mengenang peristiwa wisata. Wisatawan didasari oleh faktor asosiasi sosial yang diharapkan dengan mendokumentasikan pengalaman wisatanya di media sosial Instagram merupakan kepuasan tersendiri saat berhasil merekam suatu perjalanan.

\section{DAFTAR PUSTAKA}

Gohil, N. (2015). Role and Impact of Social Media in Tourism: A Case Study on the Initiatives of Madhya Pradesh State Tourism INTRODUCTION: REVIEW OF LITERATURE :, 5(4), 8-15.

Grijalva, E., Newmam, D. A., Tay, L., Donnellan, M. B., Harms, P. D., Robins R. W., \& Yan, T. (2015). Gender Differences in Narcissism: A Meta-Analytic Review. Psychological Bulletin, 261-310.

Ismayanti. 2010. Pengantar Pariwisata. Jakarta: PT Gramedia Widisarana.

Kang, M., \& Schuett, M. A. (2013). Determinants of Sharing Travel Experiences in Social Media. Travel \& Tourism Marketing, 93-107.

Lenhart, A., \& Fox, S. (2006). Bloggers: A Portrait of The Internet's New Storytellers. Pew Internet and American Life Project.
Munar, A. M., \& Jacobsen, J. K. (2014). Motivations for Sharing Tourism Experiences through Social Media. Tourism Management, 46-54.

Nezakati, H., Amidi, A., Jusoh, Y. Y., Moghadas, S., Aziz, Y. A., \& Sohrabinezhadtalemi, Roghayeh. 2015. Review of Social Media Potential on Knowledge Sharing and Collaboration in Tourism Industry. Procedia - Social and Behavioral Sciences, 120-125.

Pratama, Aditya H. (2017). Perkembangan Pengguna Internet di Indonesia Tahun 2016 Terbesar di Dunia. [Online]. Tersedia di: http://id.technasia.com. (Diakses 27 April 2017).

Ridings, C., Gefen, D., \& Arinze, B. (2002). Some Antecedents and Effects of Trust in Virtual Communities. Journal of Strategic Information Systems, 271295.

Sugiyono. (2017). Metode Penelitian Kuantitatif, Kualitatif, dan $R \& D$. Bandung: Alfabeta.

Suswantoro, G. (1997). Dasar-Dasar Pariwisata. Yogyakarta: Andi.

Yoo, K. H., \& Gretzel, U. (2008). What Motivates Consumers to Write Travel Online Reviews. Information Technology and Tourism, 283-295.

Zaenal, Ali. (2017). Media Sosial Paling Populer di Indonesia. [Online]. Tersedia di: www.slideshare.net/alizaenal/kompon en-media-sosial-2017. (Diakses 27 April 2017). 